\title{
Design and Simulation of an Optimal Mini-Grid Solar-Diesel Hybrid Power Generation System in a Remote Bangladesh
}

\author{
Sk. Suzauddin Yusuf*\$, Nirendra Nath Mustafi** \\ (akash09me@gmail.com;nnmustafi@gmail.com) \\ *Department of Mechanical Engineering, Faculty of Mechanical and Production Engineering, Bangladesh Army University of \\ Science and Technology, Saidpur Cantonment-5311, Bangladesh \begin{abstract}
Technology, Rajshahi-6204, Bangladesh

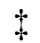

Corresponding Author; Sk. Suzauddin Yusuf, Saidpur Cantonment-5311, Bangladesh, Tel: +88 01714334475 , akash09me@gmail.com
\end{abstract} \\ **Department of Mechanical Engineering, Faculty of Mechanical Engineering, Rajshahi University of Engineering and
}

Received: 14.01.2018 Accepted: 12.02.2018

\begin{abstract}
To relief the earth from extracting of her all the conventional energy and to keep her safe for our upcoming successor, the focus of power sector must be pointed to the utilization and development of renewable energy technology. As alternative energy sources, wind and solar energies can be used to supplement the conventional energy sources predominantly in remote localities of Bangladesh. This paper presents a feasibility study of renewable resources of Kutubdia, which is an offgrid remote island. Purpose of this paper is to design and simulation of an optimal mini-grid Solar-Diesel hybrid power generation system in a remote Bangladesh to satisfy the electrical energy demands in a reliable manner by HOMER ENERGY software. To ensure uninterrupted power supply due to the remittent nature of renewable resources, a diesel generator is added. This paper analyzes the optimal size of photovoltaic (PV) panel, inverter, rectifier, and battery with a fixed capacity diesel generator, electrical load with a certain random variability, fraction of renewable electricity, excess electricity, net present cost (NPC), annualized cost, fuel summary, performance of its different components, and environmental impacts. Evaluation of results shows that the hybrid energy system can deliver energy in a remote off-grid location with an acceptable cost.
\end{abstract}

Keywords- hybrid energy system; mini-grid; renewable energy; economic analysis; environmental impact; HOMER optimizer.

\section{Introduction}

As a developing country, the electricity demand of Bangladesh is increasing since her independence in 1971. Bangladesh has as aspiration to become a high-income country by 2041 [1]. In the fiscal year 2015-2016, the highest peak generation was $9036 \mathrm{MW}$ with total installed capacity was 12,365 MW. The maximum demand in 2016 was 11,405 MW [2]. The development of energy and power infrastructure therefore pursues not only the quantity but also the quality to realize the long-term economic development. Since Bangladesh is facing to the depletion of domestic gas supply, various issues such as sustainable development harmonizing with economic optimization, improvement of power quality for the forthcoming high-tech industries, and the discipline of operation and maintenance (O\&M) for power plants need to be addressed holistically [1]. To meet this rapidly increasing demand for primary energy, the country needs to undergo a major change in energy policy. A long term plan of electricity generation against the demand up to 2030 has been incorporated in the PSMP 2010. Under the plan, generation capacity requirement in 2021 will be $24,000 \mathrm{MW}$ and in 2030 generation capacity will be 39,000 MW [2].

It is the international trend to promote renewable energy, as part of energy security as well as greenhouse gas emission reduction [1]. The objective of "Renewable energy policy 2008" of Bangladesh is to promote appropriate, efficient and environment friendly use of renewable energy; harness the potential of renewable energy resources and dissemination of technologies especially in rural, peri-urban and urban areas by encouraging and facilitating both public and private sector investment, and to achieve $10 \%$ of total energy demand from the renewable sources by 2020. [3] The public attention has remained focused on the renewable technologies as environmentally sustainable and convenient alternatives [4]. Wind and solar energies are the alternative energy sources that can be used to 
supplement the conventional energy sources particularly in Bangladesh [5]. Though these renewable sources of energy are quite variable in their output and essentially intermittent, but they are free from emission, abundant in nature, and need a little maintenance during operation.

Though Bangladesh has 42,107 km power distribution line with $11.01 \%$ distribution system loss [2], but only about $40 \%$ of rural households have access to grid electricity [6]. Many remote localities of this country along with the coastal areas are not connected to grid electricity. Electrification of these remote areas of Bangladesh is feasible by exploiting energy from enormous renewable energy sources. Hybrid power systems combine two or more energy conversion devices, or two or more fuels for the same device, that when integrated, overcome limitations inherent in either [7]. Hybrid renewable energy systems (HRES) are becoming popular as stand-alone power systems for providing electricity in remote areas due to advances in renewable energy technologies and subsequent rise in prices of petroleum products [8]. The cost of generation of electricity using renewable source is relatively low. The purpose of this study is to find the best combination of renewable energy technology from the available resources with a fixed capacity Diesel generator in a given remote location that can meet the electricity demand in a reliable and sustainable manner with the help of HOMER Energy software. This paper presents a complete design and simulation of Mini-Grid Solar-Diesel hybrid power generation system in the island Kutubdia of Bangladesh. It considerably reduces the cost of fuel consumption, and environment pollution as compared to any conventional system.

\section{HOMER Software}

HOMER Energy is the world's leading micro grid modeling software. The HOMER (Hybrid Optimization of Multiple Energy Resources) micro grid software navigates the complexities of building cost effective and reliable micro grids that combine traditionally generated and renewable power, storage, and load management. HOMER is the established global leader for micro grid design optimization and feasibility, and HOMER Energy is a nexus for the micro grid market. HOMER Energy LLC is a Boulder, Colorado based company incorporated in 2009 to commercialize the HOMER $\AA$ model, which was developed by the National Renewable Energy Lab (NREL), a division of the U.S. Department of Energy. HOMER Energy's primary focus is the continuing development, distribution, and support of HOMER [9].

\section{Mini-Grid}

A mini grid, also sometimes referred to as a "micro grid or isolated grid", can be defined as a set of electricity generators and possibly energy storage systems interconnected to a distribution network that supplies electricity to a localized group of customers. They involve small-scale electricity generation $(10 \mathrm{~kW}$ to $10 \mathrm{MW})$, which serves a limited number of consumers via a distribution grid that can operate in isolation from national electricity transmission networks. Mini-grids have a unique feature as they can operate autonomously without being connected to a centralized grid. There is environmental improvement from the use of mini-grids in terms of efficiency and reduction in carbon emissions. Hybrid mini-grid systems, for example, often incorporate a $75-99 \%$ renewable supply. Conversely as the cost of fossil fuel increases, mini-grid systems are becoming more economically attractive as the cost of renewable energy resources decrease [10].

\section{Location of Proposed Project}

Kutubdia is an upazila of Cox's Bazar district in the division of Chittagong, Bangladesh. The upazila consists of an island in the Bay of Bengal, off the coast near Chakaria, Cox's Bazar. It is located in between $21^{\circ} 43^{\prime}$ and $21^{\circ} 56^{\prime}$ north latitudes and in between $91^{\circ} 50^{\prime}$ and $91^{\circ} 54^{\prime}$ east longitudes [11]. Its population is about 125,279 [12]. Adult literacy rate is about $35 \%$ with per capita income is 4884.49 BDT. Total area of Kutubdia is $215.8 \mathrm{~km}^{2}$ in which agricultural land is 8903.22 hectors. Kutubdia is off grid area or remote area and distance from main land is 91 $\mathrm{km}$ [13].

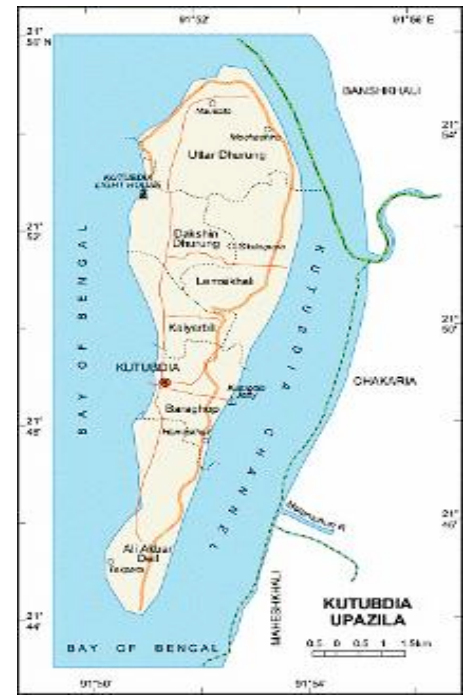

Figure 1. Kutubdia Island of Bangladesh.

\section{Feasibility of Renewable Recourse's in Kutubdia}

Both solar and wind energy are available in this island. The intensity of solar radiation is moderate but the velocity of wind is not sufficient to run a wind turbine efficiently. The potentials and feasibility of these sources are described below;

\section{1 . Solar Energy}

In HOMER Energy software, Solar Global Horizontal Irradiance (GHI) data of any place can be found from National Renewable Energy Lab database. The monthly average solar GHI data is represented by both the daily radiation data and the clearness index. The solar radiation in Kutubdia (latitude 21.761 North and longitude 92.014 East) is between $3.838 \mathrm{kWh} / \mathrm{m} 2 /$ day and 5.979 $\mathrm{kWh} / \mathrm{m} 2 /$ day. The annual average solar radiation is 4.81 $\mathrm{kWh} / \mathrm{m} 2 /$ day. Solar irradiance is high (above the average) 
from February to May, with a peak in the month of April, while solar irradiance is low in July, August, and September. Figure 2 shows the solar radiation data used in the simulations in which the left side axis represents the daily radiation data while the right one represents the clearness index.

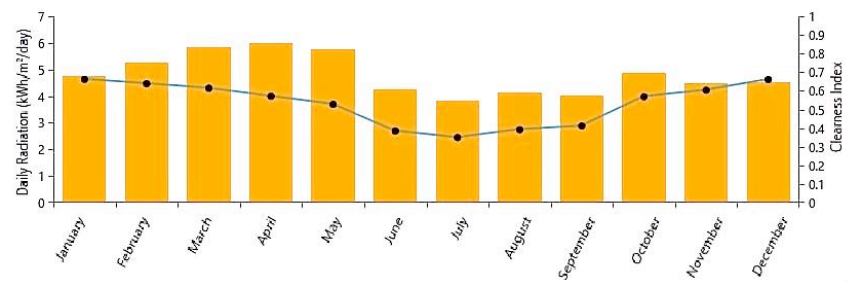

Figure 2. Monthly average solar global horizontal irradiance.

\subsection{Wind energy}

NASA Surface meteorology and solar energy database is used in HOMER Energy software to obtain the monthly average wind speed data of Kutubdia at 50 meter above the surface of earth. The monthly average wind speed in this island is fluctuated from $2.70 \mathrm{~m} / \mathrm{s}$ to $4.87 \mathrm{~m} / \mathrm{s}$. Studies have found that average wind speeds in a particular location need to exceed at least $6-8 \mathrm{~m} / \mathrm{s}$ for a small wind turbine to be economically viable. Wind speed fluctuates, which has an impact on wind electricity generation capacity and operating characteristics. In general, $3.5 \mathrm{~m} / \mathrm{s}$ $(12.6 \mathrm{kph})$ is the typical cut-in speed, when a small turbine starts generating power and $10-15 \mathrm{~m} / \mathrm{s}$ (36-54 kph) produces maximum generation power [14]. As the average wind speed in Kutubdia over a year is $3.55 \mathrm{~m} / \mathrm{s}$, which is quite low, so it is not feasible to operate a wind turbine efficiently and economically.

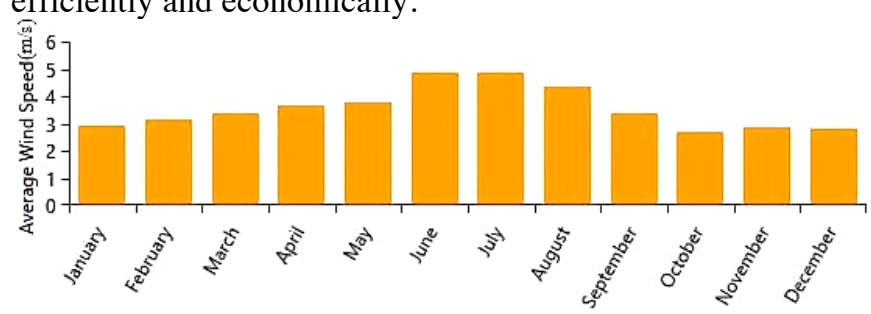

Figure 3. Monthly average wind speed data at 50 meter above the surface of earth.

\section{Electrical Load in Kutubdia}

Electrical loads of a region depend on different types of loads such as domestic load, industrial load, commercial load, irrigation load etc. Main occupations of Kutubdia are agriculture $32 \%$, fishing $4.67 \%$, agricultural laborer $24 \%$, commerce $11.88 \%$, and service $3.94 \%$ [13]. Based on data accessed from Ref. [13], the electrical load data of Kutubdia is imported in the software with $10 \%$ day to day random variability. The monthly average load profile of Kutubdia is presented in Fig.4. The yearly average load is $629.51 \mathrm{~kW}$ with energy consumption $15,108.21 \mathrm{kWh} /$ day. The maximum peak load $1,167.5 \mathrm{~kW}$ occurs in the month of August.

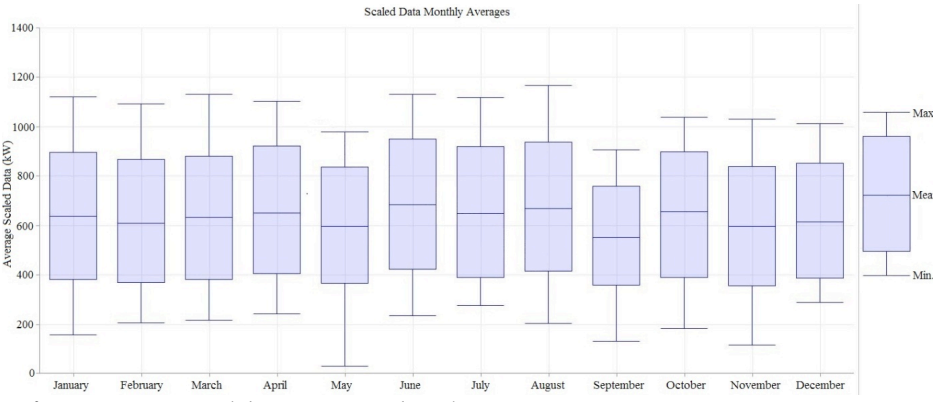

Figure 4. Monthly average load Data.

\section{Proposed Hybrid System}

According to electrical load data, availability of resources, and different economic aspects, an optimal mini-grid hybrid power generation system is developed by HOMER Energy software. The proposed hybrid system consists of Diesel generator, PV panels, Converters, and Batteries. This power generation system is designed for 25 years lifetime. The optimum size of all the components is determined by HOMER software.

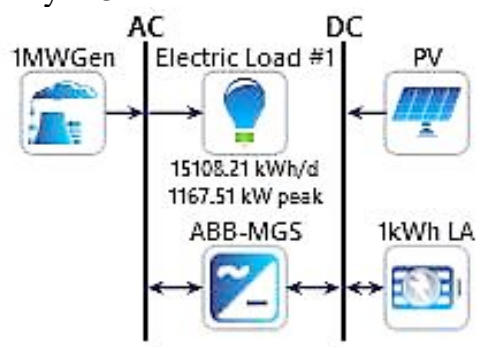

Figure 5. Diagram of power generation system.

Table 1. System architecture

\begin{tabular}{|l|l|}
\hline Flat plate PV & $1,574 \mathrm{~kW}$ \\
\hline Generator & $1,000 \mathrm{~kW}$ \\
\hline Lead Acid Battery & $2,883 \mathrm{kWh}$ \\
\hline Inverter & $1,000 \mathrm{~kW}$ \\
\hline Rectifier & $600 \mathrm{~kW}$ \\
\hline Dispatch strategy & Load Following \\
\hline
\end{tabular}

Figure 5 shows the schematic diagram of proposed hybrid system for HOMER simulation in which $1 \mathrm{MW}$ diesel generator is connected to the $\mathrm{AC}$ bus as it produces $\mathrm{AC}$ output. Battery bank and PV panels are connected to the DC bus. Converter is placed between the two buses. Load is connected to the system through AC bus. The sizes of each component are shown in Table 1. 


\section{Simulation Results and Analysis}

Monthly average electrical demand and generation, output of $1 \mathrm{MW}$ generator and PV panels, percentage of renewable energy, fuel summery, performance of converter and batteries, emissions, cash flow and cost summery etc. are analyzed in this simulation by HOMER ENERGY software. Result of simulation is divided into economic analyses, electrical analyses, and environmental impact which are described in the following articles. Dispatch strategy of this simulation was load following.

\subsection{Economic analysis}

Economic analysis consists of cash flow in 25 years by type of cost, net present costs and annualized costs by components. Project life time is expected as 25 years. Cash flow in 25 years by cost type is presented in fig.6 and net present costs by components are shown in fig.7. Different types of costs considered are replacement cost, fuel cost, salvage cost, operating cost, and capital cost. Price of diesel in Bangladesh is $0.80 \$ / \mathrm{L}$ and inflation rate is $6.04 \%$. Fuel cost for $1 \mathrm{MW}$ fixed capacity generator is $808,245.19 \$ / y r$. From this simulation, the cost of electricity is found $0.2386 \$ / \mathrm{kWh}$ and operating cost is found $1,091,205.00 \$ / y r$. Net present costs by components and annualized costs by components are shown in Table 2 and Table 3 respectively. HOMER's optimization process is focused on finding the best possible optimal system configuration from the successfully simulated configurations. It finds the optimal system by determining the lowest possible initial capital costs, operating costs, net present costs, and cost of per unit electricity.

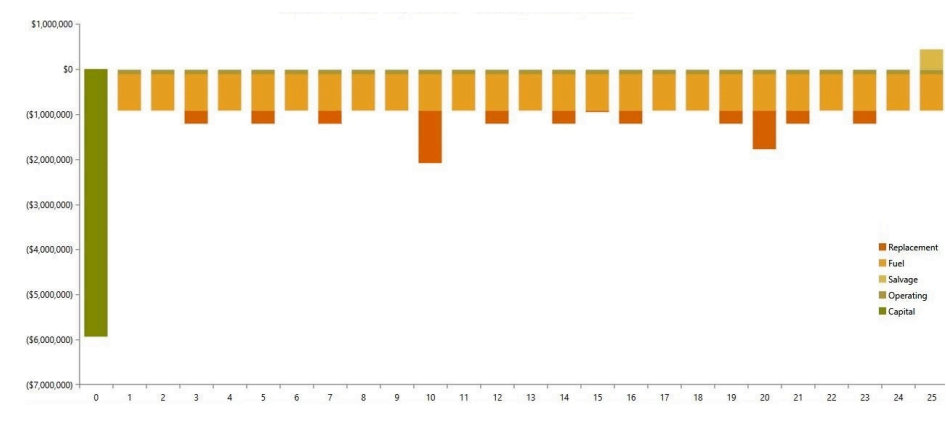

Figure 6. Cash flow in 25 years by cost type.

Table 2. Net Present Costs by components

\begin{tabular}{|c|c|c|c|c|c|c|}
\hline \multirow[t]{2}{*}{$\begin{array}{l}\text { Com } \\
\text { pone } \\
\text { nt }\end{array}$} & $\begin{array}{c}\text { Capi } \\
\text { tal }\end{array}$ & $\begin{array}{c}\text { Repla } \\
\text { cemen } \\
\mathbf{t}\end{array}$ & $\begin{array}{c}\text { O\& } \\
\mathbf{M}\end{array}$ & Fuel & $\begin{array}{l}\text { Salv } \\
\text { age }\end{array}$ & Total \\
\hline & $(\$)$ & $(\$)$ & $(\$)$ & $(\$)$ & $(\$)$ & $(\$)$ \\
\hline PV & $\begin{array}{c}4,721 \\
, 562 . \\
5\end{array}$ & 0.0 & $\begin{array}{c}415,5 \\
03.9\end{array}$ & 0.0 & 0.0 & $\begin{array}{c}5,137, \\
066.4\end{array}$ \\
\hline $\begin{array}{l}\text { Gene } \\
\text { rator }\end{array}$ & $\begin{array}{c}300,0 \\
00.0\end{array}$ & $\begin{array}{c}3,161, \\
617.8\end{array}$ & $\begin{array}{c}1,738 \\
, 202 . \\
8\end{array}$ & $\begin{array}{c}21,33 \\
8,002 . \\
0\end{array}$ & $\begin{array}{c}8,87 \\
6.3\end{array}$ & $\begin{array}{c}26,52 \\
8,946 . \\
3 \\
\end{array}$ \\
\hline $\begin{array}{c}\text { Batte } \\
\text { ry }\end{array}$ & $\begin{array}{c}864,9 \\
00.0\end{array}$ & $\begin{array}{l}1,841, \\
521.3\end{array}$ & $\begin{array}{c}761,1 \\
23.7\end{array}$ & 0.0 & $\begin{array}{c}479, \\
822 . \\
8\end{array}$ & $\begin{array}{c}2,987, \\
722.2\end{array}$ \\
\hline $\begin{array}{l}\text { Conv } \\
\text { erter }\end{array}$ & $\begin{array}{c}40,00 \\
0.0\end{array}$ & $\begin{array}{c}42,574 \\
.2\end{array}$ & $\begin{array}{c}13,20 \\
0.2\end{array}$ & 0.0 & $\begin{array}{l}14,7 \\
93.9\end{array}$ & $\begin{array}{c}80,98 \\
0.5\end{array}$ \\
\hline $\begin{array}{c}\text { Syste } \\
\text { m }\end{array}$ & $\begin{array}{c}5,926 \\
, 462 . \\
5\end{array}$ & $\begin{array}{c}5,045, \\
713.4\end{array}$ & $\begin{array}{c}2,928 \\
, 030 . \\
6\end{array}$ & $\begin{array}{c}21,33 \\
8,002 . \\
0\end{array}$ & $\begin{array}{c}503, \\
493 . \\
1\end{array}$ & $\begin{array}{c}34,73 \\
4,715 . \\
4\end{array}$ \\
\hline
\end{tabular}

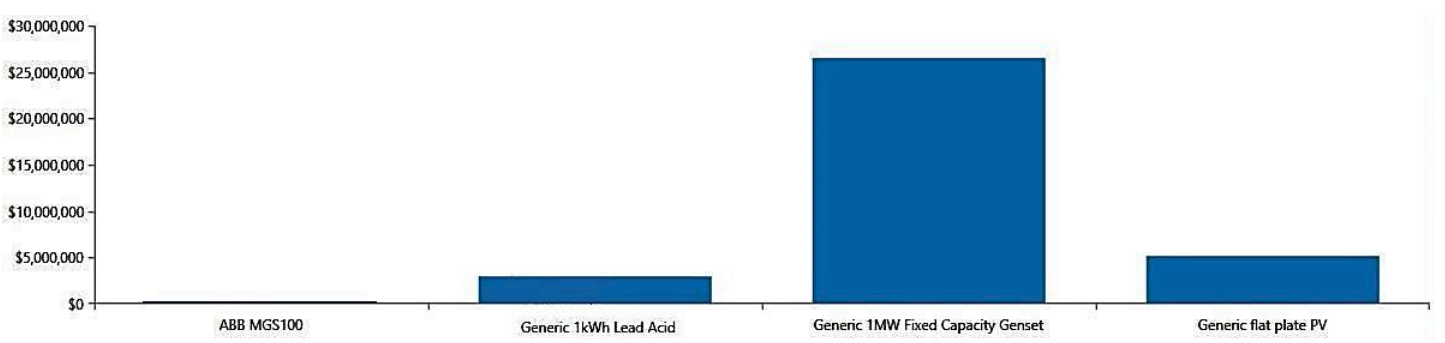

Figure 7. Net present cost by component.

Table 3. Annualized Costs by components

\begin{tabular}{|l|r|r|r|r|r|c|}
\hline $\begin{array}{c}\text { Com } \\
\text { pone } \\
\text { nt }\end{array}$ & $\begin{array}{c}\text { Capi } \\
\text { tal }\end{array}$ & $\begin{array}{c}\text { Repla } \\
\text { cemen } \\
\mathbf{t}\end{array}$ & $\begin{array}{c}\text { O\& } \\
\mathbf{M}\end{array}$ & Fuel & $\begin{array}{c}\text { Salv } \\
\text { age }\end{array}$ & Total \\
\cline { 2 - 7 } & $(\$ / y r)$ & $(\$ / y r)$ & $(\$ / y r)$ & $(\$ / y r)$ & $\begin{array}{c}(\$ / y r \\
)\end{array}$ & $(\$ / y r)$ \\
\hline PV & 178,8 & 0.00 & 15,73 & 0.00 & 0.00 & 194,5 \\
& 44.31 & & 8.54 & & & 82.85 \\
\hline Gene & 11,36 & 119,75 & 65,84 & 808,2 & 336. & 1,004, \\
rator & 3.46 & 6.40 & 0.00 & 45.19 & 22 & 868.8 \\
\hline
\end{tabular}

\begin{tabular}{|l|r|r|r|r|r|r|}
\hline $\begin{array}{l}\text { Batte } \\
\text { ry }\end{array}$ & $\begin{array}{r}32,76 \\
0.86\end{array}$ & 69,753 & 28,83 & 0.00 & 18,1 & 113,1 \\
& & & 0.00 & & 74.8 & 69.55 \\
& & & & & \\
\hline $\begin{array}{l}\text { Conv } \\
\text { erter }\end{array}$ & 1,515 & $1,612$. & 500.0 & 0.00 & 560. & $3,067$. \\
& .13 & 64 & 0 & & 37 & 40 \\
\hline $\begin{array}{l}\text { Syste } \\
\text { m }\end{array}$ & 224,4 & 191,12 & 110,9 & 808,2 & 19,0 & 1,315, \\
& & 2.56 & 08.54 & 45.19 & 71.4 & 688.6 \\
& & & & 2 & 3 \\
\hline
\end{tabular}




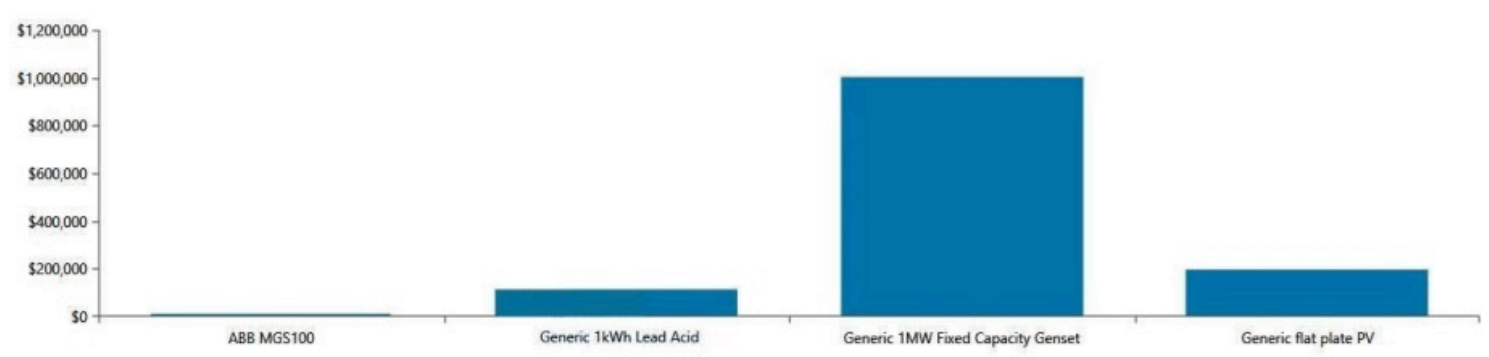

Figure 8. Annualized cost by component.

\subsection{Electrical Analysis}

Simulation results and analysis of generator and PV panel output, competitive electric production and renewable energy fraction, and performance of battery and converter are described in this section.

\subsubsection{Generator Output}

In this proposed system, a fixed capacity $1 \mathrm{MW}$ ac diesel generator is used. The fuel consumption at full load is around 260 liter/hour. Initial capital cost of generator is $\$ 300,000.00$ and operation and maintenance cost is $\$ 10.00 /$ hour. The expected life time of this diesel generator is 15,000 hours. No heat recovery system is considered in the system. Figure 9 shows the generator power output over different months of the year. From this simulation, the electricity production of generator is found $3,762,830$ $\mathrm{kWh} / \mathrm{yr}$ and its capacity factor is $43.0 \%$. Total hours of operation of this generator are $6,584 \mathrm{hrs} / \mathrm{yr}$ and its specific fuel consumption is $0.268 \mathrm{~L} / \mathrm{kWh}$. Generator's mean electrical efficiency is $37.9 \%$ with mean electrical output is $572 \mathrm{~kW}$. Fuel consumption by generator in a year is represented by fig.10. Average rate of fuel consumption is $2,768 \mathrm{~L} /$ day and $115 \mathrm{~L} / \mathrm{hr}$. Specific fuel consumption of this generator is $0.268 \mathrm{~L} / \mathrm{kWh}$ and it consumes diesel $1,010,306 \mathrm{~L} / \mathrm{yr}$.

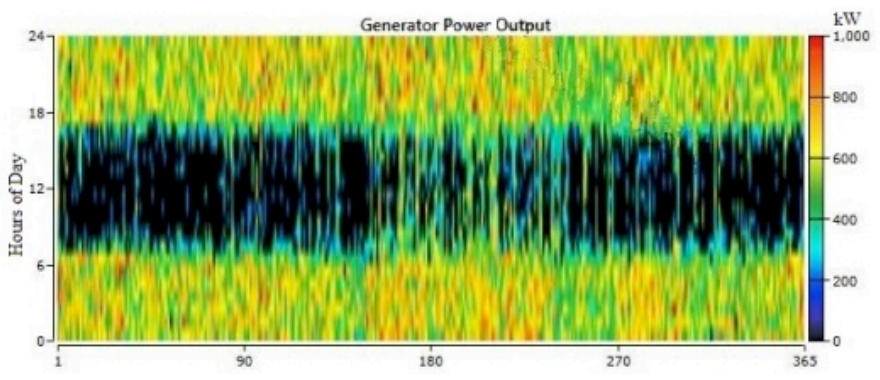

Figure 9. Generator power output in a year.

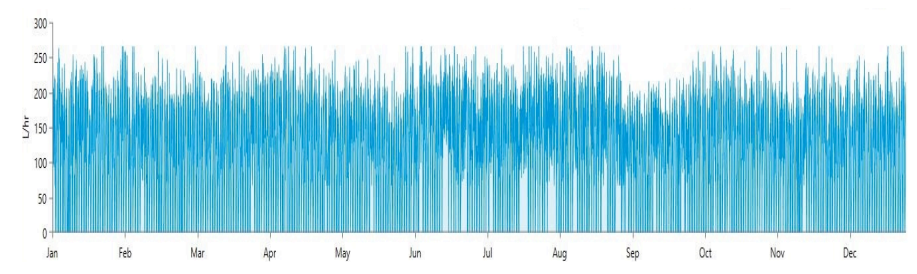

Figure 10. Fuel consumption by generator in a year.

\subsubsection{PV output}

Flat plate PV panel is considered in this proposed system to harness renewable energy. Initial capital cost of generator is $\$ 3,000.00$ and operation and maintenance cost is $\$ 10.00$ /year. Efficiency at standard test conditions is $13 \%$ and nominal operating cell temperature is $47^{\circ}$. By using Homer optimizer, the size of flat plate PV panel is found $1574 \mathrm{~kW}$. The flat plate $\mathrm{PV}$ panels produce $2,396,861 \mathrm{kWh} / \mathrm{yr}$, and $6,567 \mathrm{kWh} /$ day, and it's capacity factor is $17.4 \%$. Total hours of operation of this flat plate $\mathrm{PV}$ panels are 4,371 hrs/yr and its maximum output is $1,560 \mathrm{~kW}$. Figure 11 shows the PV panels power output in a year.

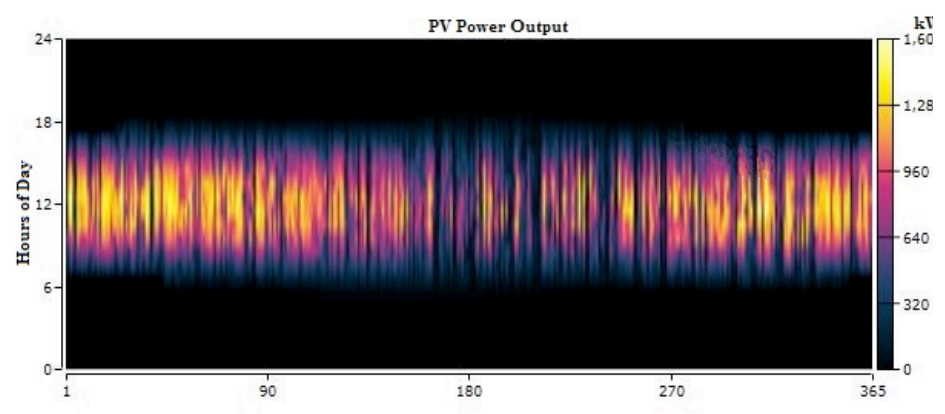

Figure 11. PV power output in a year.

\subsubsection{Comparative electrical production}

Monthly average electricity produces by solar-diesel power generation system is shown in fig.12. Green color indicates electricity production by generator and orange color indicates electricity production by PV panels. $2,396,861 \mathrm{kWh} /$ year energy is generated by PV panels and $3,762,830 \mathrm{kWh} /$ year energy is generated by generator. So, renewable energy fraction is $31.8 \%$. 


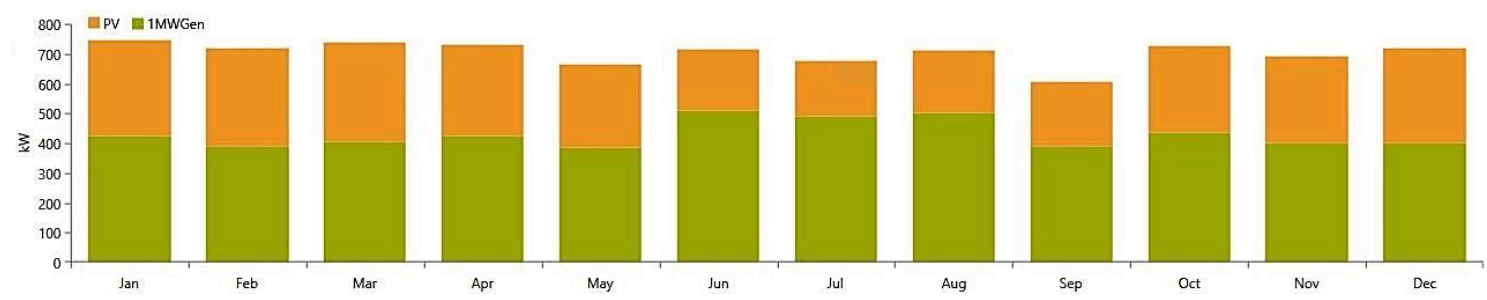

Figure 12. Power output in a year by Generator and PV panels.

\subsubsection{Performance of battery:}

Batteries are used to store excess electricity and provided this energy during shortage. Initial capital costs of 2,883 kWh Lead Acid batteries are $\$ 864,900.00$ and expected life time is 10 years. Minimum state of charge is fixed to $40 \%$ and bus voltage is $12 \mathrm{~V}$. Figure 13 shows the state of charge of battery in a year. Annual throughput of batteries is $75,684 \mathrm{kWh} / \mathrm{yr}$ and lifetime throughput is $756,843 \mathrm{kWh} / \mathrm{yr}$. As minimum state of charge is fixed to $40 \%$, so it's usable nominal capacity is $1,731 \mathrm{kWh}$. Total energy input in a year is $84,432 \mathrm{kWh}$ and output is 67,694 $\mathrm{kWh}$.

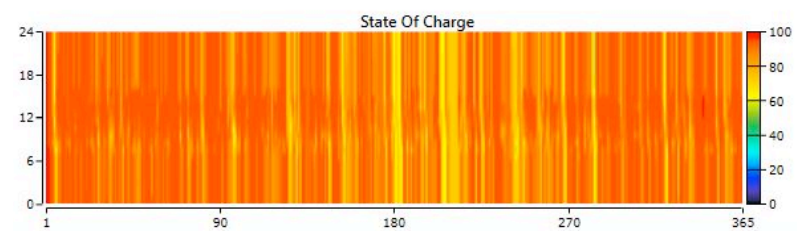

Figure 13. State of charge of battery in a year.

\subsubsection{Performance of Converter}

A converter is used in this proposed project to convert ac power to dc or vice versa. Capacity of inverter is 1000 $\mathrm{kW}$ and rectifier is $600 \mathrm{~kW}$. Initial capital cost of ABB MGS100 converter is $\$ 40,000.00$ and 25 years expected life time. Figure 14 represents the inverter output in a year and fig. 15 shows the rectifier output in a year. Mean output of inverter is $200 \mathrm{~kW}$ and maximum output is 901 $\mathrm{kW}$. Total hours of operation of inverter and rectifier are $4,886 \mathrm{hr} /$ year and $8.00 \mathrm{hr} /$ year respectively.

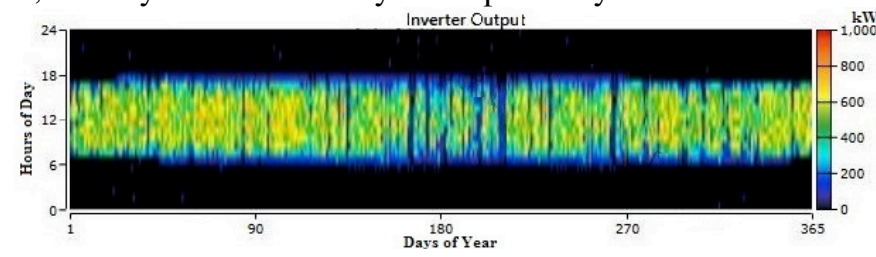

Figure 14. Inverter output in a year.

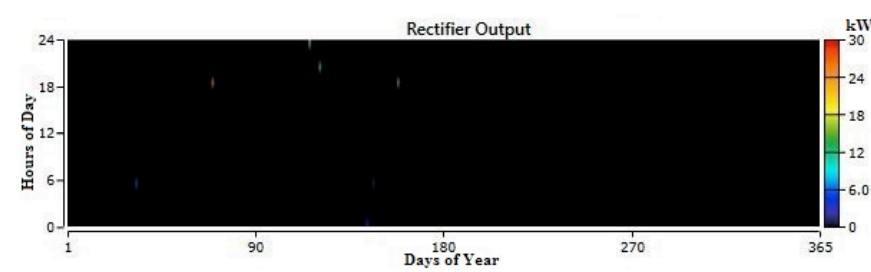

Figure 15. Rectifier output in a year.

\subsection{Environmental impact}

Solar-diesel hybrid system reduces a significant amount of emission due to use of renewable energy technology. It decreases the consumption of fossil fuel. So, it is a more environment friendly power generating system. The emission of different gases is determined by simulation which shown in Table 4.

Table 4. Emission of different pollutants

\begin{tabular}{|l|l|}
\hline \multicolumn{1}{|c|}{ Pollutant } & \multicolumn{1}{c|}{ Emissions $(\mathrm{kg} / \mathrm{yr})$} \\
\hline Carbon dioxide & $2,649,251$ \\
\hline Carbon monoxide & 13,706 \\
\hline Unburned hydrocarbons & 727 \\
\hline Particulate matter & 117 \\
\hline Sulfur dioxide & 6,476 \\
\hline Nitrogen oxides & 2,627 \\
\hline
\end{tabular}

\section{Conclusion}

Hybrid power generation systems are attractive, cost competitive, and a common solution of energy demand in remote off grid areas. In order to utilize renewable energy resources efficiently and economically with a reliable conventional energy source, an optimal Mini-Grid SolarDiesel Hybrid Power Generation system is developed with the help of HOMER ENERGY software. As Kutubdia is a remote island of Bangladesh, so this power generation system can be a perfect long term solution to meet the energy demand. Cost of electricity found from this simulation is $\$ 0.2386 / \mathrm{kWh}$. Performance of different components in this system, electrical demand, fuel summary, emissions, and economic aspects are also analyzed in this simulation.

\section{Acknowledgements}

The author thank to Dr. Nirendra Nath Mustafi Professor, Department of Mechanical Engineering, Rajshahi University of Engineering \& Technology for his support, guidance and encouragement throughout this research.

\section{References}

[1] Power System Master Plan 2016 Final Report.

Available online: http://powerdivision.portal.gov.bd/ sites/default/files/files/powerdivision.portal.gov.bd/pa ge/4f81bf4d_1180_4c53_b27c_8fa0eb11e2c1/\%28E \%29_FR_PSMP2016_Summary_revised.pdf. (Reports)

[2] Bangladesh Power Development Board (BPDB). Annual Report 2015-2016, BPDB, Dhaka. Available online: http://www.bpdb.gov.bd/download/annual_ 
report/ANNUAL_ REPORT 2015- 2016. PDF. (Reports)

[3] Renewable Energy Policy of Bangladesh, Power Division, Ministry of Power Energy and Mineral Resources, Government of the People's Republic of

[4] Rajesh Kumar, R.A.Gupta, Ajay Kumar Bansal, Economic analysis and power management of a standalone wind/photovoltaic hybrid energy system using biogeography based Optimization algorithm, Swarm and Evolutionary Computation 8(2013) 33-43. (Article)

[5] Sanjoy Kumar Nandi, Mohammad Nasirul Hoque, Himangshu Ranjan Ghosh, Swapan Kumar Roy, Potential of Wind and Solar Electricity Generation in Bangladesh, International Scholarly Research Network ISRN Renewable Energy, Volume 2012, Article ID 401761. (Article)

[6] World Bank. Lighting Up Rural Communities in Bangladesh. January 2015. Available online:http://www.worldbank.org/en/news/feature/201 4/01/15/lighting-up-rural- communities-inbangladesh. (accessed on 22 December 2017)

[7] M. Prashanth Reddy, M. Vijay Rao, B. Sreedhar Reddy, Grid Connected PV-FC Hybrid System and its Power Management, INTERNATIONAL JOURNAL OF PROFESSIONAL ENGINEERING STUDIES, Volume I/Issue 2/DEC 2013. (Article)

[8] Hybrid renewable energy system. Available online: http:/en.m.wikipedia.org/wiki/ Hybrid _renewable_energy_system/. (last accessed on 23/12/2017)

[9] HOMER ENERGY. Available online: https://www.homerenergy.com/.(last accessed on 26/12/2017)
Bangladesh. 18 December 2008. Available online: http://www.iea.org/media/pams/bangladesh/Banglades h_RenewableEnergyPolicy_2008.pdf. (accessed on 23 December 2017).

[10] Mini Grids. Available online: https://energypedia.info/wiki/Mini_Grids.(accessed on 26 December 2017)

[11] Kutubdia Upazila, BANGLAPEDIA. Available online: http://en.banglapedia.org/ index. php?title=Kutubdia_Upazila . (accessed on 26 December 2017)

[12] Kutubdia Upazila, WIKIPEDIA. Available online: https://en.wikipedia.org/ wiki/Kutubdia_Upazila. (accessed on 26 December 2017)

[13] Md. Tanjil Sarker, Md. Anisur Rahman, Prf. Dr. Zahid Hasan Mahmud, Electricity Demand Load Forecasting for a Remote Area of Bangladesh, International Journal of Scientific \& Engineering Research, Volume 8, Issue 1, January-2017 265-277. (Article)

[14] Wind turbine system. Available online: http://www.level.org.nz/energy/renewable-electricitygeneration/wind-turbine-systems/.(accessed on 21 December 2017) 